\title{
UJI BERBAGAI JENIS MIKROORGANISME LOKAL (MOL) TERHADAP PERTUMBUHAN DAN HASIL TANAMAN PAKCHOY (Brassica Rapa L) SECARA HIDROPONIK
}

\author{
Tony Setiawan $^{1}$, Rahmawaty Rahman ${ }^{1}$, Yulianti Rasud ${ }^{1}$ \\ ${ }^{1}$ Program Studi Agroteknologi, Fakultas Pertanian, Sekolah Tinggi Ilmu Pertanian Mujahidin Tolitoli \\ Email : yulirasud.stip@gmail.com
}

Diterima: 12 Maret 2020

Disetujui: 3 April 2020

\begin{abstract}
Local microorganisms (MOL) are fermented solutions made from various local resources. MOL solution contains micro and macro nutrients as well as containing bacteria that have the potential to remodel organic matter, stimulate growth, and as a controlling agent for pests and plant diseases, so that MOL can be used both as a decomposer, biological fertilizer and organic pesticides, especially as a fungicide. The aim of this experiment was to determine the most suitable MOL types of the growth and yield of pakchoy plants. This experiment used a Completely Randomized Design (CRD) with treatments to be tried, namely various types of MOL at a concentration of $10 \mathrm{ml}$. L-1 consisting of 5 treatments, namely B1 = Control (without MOL), B2 = MOL Rice, B3 = MOL Vegetables , B4 = MOL Banana weevil, B5 = MOL Banana skin. The results showed that the administration of rice mole was a better treatment of plant height, number of leaves, leaf length, leaf width until the fourth week of $25.94 \mathrm{~cm}$ each; 19.98 strands; $9.59 \mathrm{~cm} ; 5.71 \mathrm{~cm}$; and the fresh weight of pakcoy plants is $68.48 \mathrm{~g}$.
\end{abstract}

Keyword : Local Mikroorganisms, Pakchoy, Hidroponic

\begin{abstract}
ABSTRAK
Mikroorganisme Lokal (MOL) adalah larutan hasil fermentasi yang berbahan dasar dari berbagai sumber daya lokal. Larutan MOL mengandung unsur hara mikro dan makro serta mengandung bakteriyang berpotensi sebagai perombak bahan organik, perangsang pertumbuhan, dan sebagai agen pengendali hama dan penyakit tanaman, sehingga MOL dapat digunakan baik sebagai dekomposer, pupuk hayati maupun pestisida organik terutama sebagai fungisida.Penelitian ini bertujuan untuk untuk menentukan jenis MOL yang lebih baik terhadap pertumbuhan dan hasil tanaman pakcoy. Penelitian ini menggunakan Rancangan Acak Lengkap (RAL) dengan perlakuan yang akan dicobakan yaitu berbagai jenis MOL pada konsentrasi $10 \mathrm{ml} . \mathrm{L}-1$ yang terdiri dari 5 perlakuan, yaitu B1 = Kontrol $($ Tanpa MOL), B2 = MOL Nasi , B3 = MOL Sayuran, B4 = MOL Bonggol Pisang, B5 = MOL Kulit Pisang. Data diolah dengan analisis ragam dan perbedaan antar perlakuan ditentukan dengan Uji BNJ 5\%. Hasil penelitian menunjukkan pemberian mol nasi merupakan perlakuan yang lebih baik terhadap tinggi tanaman, jumlah daun, panjang daun, lebar daun hingga minggu keempat yaitu masing-masing $25,94 \mathrm{~cm} ; 19,98$ helai; $9,59 \mathrm{~cm} ; 5,71 \mathrm{~cm}$; dan berat segar tanaman pakcoy yaitu $68,48 \mathrm{~g}$.
\end{abstract}

Kata Kunci : Mikroorganisme Lokal, Pakchoy, Hidroponik

\section{PENDAHULUAN}

Pakcoy (Brassica rapa L)adalah jenis tanaman sayur-sayuran yang termasuk keluarga Brassicaceae. Tumbuhan pakcoy berasal dari China dan telah dibudidayakan setelah abad ke5 secara luas di China selatan dan China pusat serta Taiwan. Sayuran ini merupakan introduksi baru di Jepang dan masih sefamili dengan Chinese vegetable. Saat ini pakcoy dikembangkan secara luas di Filipina dan Malaysia, di Indonesia dan Thailand (Adiwilaga, 2010).
Berdasarkan data Badan Pusat Statistik dan Direktorat Jendral Hortikultura (2018) produksi sayuran sawi di Indonesia dari tahun 2016hingga 2018mengalami kenaikan produksi dari 601.198 ton menjadi 635.982 ton. Kenaikan produksi sayuran sawi mengindikasikan bahwa permintaan masyarakat cukup tinggi, tidak hanya untuk keperluan rumah tangga tetapi juga untuk industri makanan seperti di hotel dan restaurant, untuk memenuhi kebutuhan masyarakat, yang kian meningkat diperlukan berbagai upaya alternatif untuk dilakukan. Selain itu, beralihnya fungsi lahan pertanian 
menjadi daerah perindustrian menyebabkan semakin sempitnya lahan pertanian yang potensial untuk bercocok tanam. Oleh karena itu diperlukan adanya suatu sistem bercocok tanam yang dapat menggunakan lahan sempit tanpa mengurangi tingkat produktivitas pertanian dan dapat menghasilkan kualitas produksi yang lebih tinggi. Salah satu teknologi pertanian yang dapat digunakan adalah teknologi budidaya tanaman secara hidroponik.

Sistem budidaya hidroponik merupakan budidaya tanaman tanpa menggunakan tanah sebagai media tanaman dengan penambahan nutrisi hara untuk pertumbuhan (Perwitasari, 2012). Keberhasilan budidaya hidroponik salah satunya ditentukan oleh kebutuhan nutrisi. Salah satu nutrisi yang dapat dimanfaatkan oleh tanaman adalah penggunaan Mikroorganisme Lokal (MOL). MOL adalah larutan hasil fermentasi yang berbahan dasar dari berbagai sumber daya lokal. Larutan MOL mengandung unsur hara mikro dan makro serta mengandung bakteri yang berpotensi sebagai perombak bahan organik, perangsang pertumbuhan, dan sebagai agen pengendali hama dan penyakit tanaman, sehingga MOL dapat digunakan baik sebagai dekomposer, pupuk hayati maupun pestisida organik terutama sebagai fungisida (Purwasasmita, 2009; Julita et al., 2013). MOL dapat diperoleh dengan memanfaatkan limbah pertanian seperti nasi busuk,sayur-sayuran, buah-buahan dan bonggol pisang. Keunggulan penggunaan MOL adalah dapat diperoleh dengan biaya murah.

Maspary (2012), menyatakan dalam mol bonggol pisang mengandung 7 mikroorganisme yang sangat berguna bagi tanaman yaitu : Azospirillium, Azotobacter, Bacillus, Aeromonas, Aspergillus, mikroba pelarut phospat dan mikroba selulotik. Tidak hanya itu MOL bonggol pisang juga tetap bisa digunakan untuk dekomposer atau mempercepat proses pengomposan. Mol berbahan nasi busuk mengandung mikroorganisme Azotobacter yang bermanfaat sebagai dekomposer dan dimanfaatkan sebagai pupuk cair ataupun pupuk hayati yang bisa langsung diaplikasikan pada media tanam (Julita et.al, 2013). Limbah sayuran dapat dimanfaatkan menjadi pupuk organik cair (POC) karena mengandung banyak unsur hara makro maupun mikro (Indarjaya dan Suhartini, 2018). Selanjutnya, Wulandarai (2009) menyatakan kulit pisang juga dapat dimanfaatkan sebagai pupuk organik karena menyediakan unsur hara bagi tanaman. Tujuan penelitian ini adalah untuk menentukan jenis MOL yang lebih baik terhadap pertumbuhan dan hasil tanaman pakcoy.

\section{METODE}

\section{Lokasi Penelitian}

Penelitian ini dilaksanakan di dalam Screenhousedi Kelurahan Nalu, Kecamatan Baolan, Kabupaten Tolitoli, Provinsi Sulawesi Tengah pada bulan November hingga Desember 2017.

\section{Jenis dan Desain Penelitian}

Penelitian ini menggunakan Rancangan Acak Lengkap (RAL) dengan perlakuan yang akan dicobakan yaitu berbagai jenis MOL pada konsentrasi 10 ml.L-1 yang terdiri dari 5 perlakuan, yaitu : $\mathrm{B} 1$ = Tanpa pemberian MOL (kontrol), B2 = MOL Kulit Pisang, B3 = MOL Bonggol Pisang, B4 = MOL Sayuran, B5 = MOL Nasi. Setiap perlakuan diulang sebanyak 3 kali sehingga terdapat 15 unit percobaan. Tiap unit percobaan menggunakan 6 tanaman dengan demikian terdapat total 90 tanaman. Semua populasi tanaman dalam penelitian ini dijadikan tanaman sampel. Sistem hidroponik yang dipakai pada penelitian ini adalah system rakit apung. Apabila analisis ragam menunjukkan adanya pengaruh perlakuan nyata atau sangat nyata maka dilanjutkan Uji Beda Nyata Jujur (BNJ) taraf 5\%.

\section{Alat dan Bahan Penelitian}

Alat yang akan digunakan pada penelitian ini adalah mistar, timbangan, label perlakuan, kamera dan alat tulis menulis. Bahan yang akan digunakan pada penelitian ini adalah : Benih Pakcoy varietas Nauli F1, MOL Nasi, sayuran, bonggol pisang dan kulit pisang dengan konsentrasi 10 ml.L-1, Nutrisi Hidroponik AB Mix $5 \mathrm{ml} \mathrm{L-1}$, Net pot ukuran 5,5 x $5 \mathrm{~cm}$, Kain flanel, Rockwoll, Styrofoam dan bak hidroponik ukuran 36 × 26,5 x $10 \mathrm{~cm}$.

\section{Pelaksanaan Penelitian}

Pembuatan Mikroorganisme Lokal (MOL) Nasi Menyiapkan 10 kepal nasi dan disimpan didalam toples selama 1 minggu, Setelah itu akan tumbuh jamur berwarna merah kekuningan. Memindahkan nasi basi tersebut pada ember ukuran $10 \mathrm{~L}$, lalu memasukkan air kelapa sebanyak $2 \mathrm{~L}, 10 \mathrm{sdm}$ gula pasir, $10 \mathrm{gr}$ terasi dan $4 \mathrm{~L}$ air suling. Kemudian diaduk dan tutup wadahnya. Difermentasikan selama 1 minggu. Setelah itu, penutup wadahnya dibuka dan akan tercium bau yang menyengat menandakan proses fermentasi telah berhasil. 
Aduk larutan tersebut dan saring kedalam botol sehingga MOL nasi tersebut siap untuk digunakan.

Pembuatan Mikroorganisme Lokal (MOL) Kulit Pisang

Melumatkan atau mencincang $1 \mathrm{~kg}$ kulit pisang, kemudian dicampurkan dengan 2 liter air beras, masukkan 2 ons gula merah aduk rata, masukkan dalam drum atau tong plastik menutupnya dengan plastik rapat beri lubang udara dengan cara memasukkan selang plastik yang dihubungkan dengan botol yang sudah terisi air, ujung selang plastik harus terendam dalam air. Dibiarkan selama 15 hari.

Pembuatan Mikroorganisme Lokal (MOL) Bonggol Pisang

Bahan yang digunakan dalam pembuatan MOL bonggol pisang adalah air cucian beras 4 liter sebagai sumber karbohidrat, gula merah 2 ons sebagai sumber glukosa dan bonggol pisang $2 \mathrm{~kg}$ sebagai sumber mikroorganisme. Bonggol pisang dan gula merah yang telah dicacah kemudian dimasukkan ke dalam air cucian beras dan difermentasi selama 2-3 minggu dalam kondisi anaerob (Sari, et. al. 2012).

\section{Pembuatan Mikroorganisme Lokal (MOL) Sayuran}

Pembuatan MOL sayur-sayuran dilakukan dengan menghaluskan limbah sayuran yang telah disediakan sebanyak $2 \mathrm{~kg}$ kemudian dicampurkan dengan gula merah dan air kelapa sesuai dengan komposisi pada bahan baku utama, ditambahkan dengan 2 ons gula merah, air kelapa sebanyak 3 liter dan kemudian akan difermentasikan secara anaerob selama 3 minggu (Palupi, 2015). Setelah itu, penutup wadahnya dibuka dan akan tercium bau yang menyengat menandakan proses fermentasi telah berhasil. Aduk larutan tersebut dan saring kedalam tempat yang sudah disiapkan.

\section{Penyiapan Bibit}

Sebelum dilakukan penanaman terlebih dahulu benih tanaman pakcoy disemai pada media rockwoll yang telah dipotong-potong dengan ukuran $2 \times 2 \mathrm{~cm}$. Tiap potongan rockwoll ditanam 1 benih pakcoy. Setelah bibit berumur 14 hari atau telah memiliki 4 helai daun, selanjutnya bibit dipindahkan ke bak penanaman hidroponik.

\section{Penanaman}

Penanaman dilakukan dengan cara bibit dimasukkan ke dalam net pot yang telah diberi sumbu, kemudian net pot diletakkan ke dalam Styrofoam yang dilubangi sesuai ukuran net pot dan sudah terpasang pada bak hidroponik.

\section{Pemeliharaan}

Pemeliharaan dilakukan dengan memberikan larutan nutrisi yang diperlukan oleh tanaman yaitu berbagai jenis mol (nasi, sayuran, bonggol pisang dan kulit pisang) dengan konsentrasi 10 ml.L-1 air dan larutan nutrisi $\mathrm{AB}$ MIX dengan konsentrasi 5 ml.L-1 air. Larutan nutrisi dimasukkan kedalam bak hidroponik sebelum bibit pakchoy dipindahkan. Apabila larutan mulai berkurang dalam bak hidroponik, maka dilakukan penambahan larutan sesuai perlakuan. Selama pemeliharaan larutan nutrisi dijaga dengan kepekatan nutrisi 1050-1400 ppm pada $\mathrm{pH} 7$.

Panen

Pemanenan dilakukan dengan cara mencabut akar tanaman dalam netpot, pada saat tanaman telah berumur 4 MST. Selain dari penentuan umur, penentuan panen dapat dilakukan dengan cara melihat fisik tanaman seperti warna, bentuk dan ukuran daun. Apabila daun pada bagian bawah telah berwarna kuning, maka pakchoy dapat segara dipanen.

\section{HASIL DAN PEMBAHASAN}

Tinggi Tanaman (cm)

Hasil analisis ragam menunjukkan bahwa perlakuan berbagai jenis MOLberpengaruh nyata terhadap tinggi tanaman pakcoy pada umur 1 hingga 4 MST. Rata-rata tinggi tanaman umur 1-4 MST disajikan pada Tabel 1.

Tabel 1. Rata-Rata Tinggi Tanaman Pakcoy (cm) Umur 1, 2, 3 dan 4 MST

\begin{tabular}{|c|c|c|c|c|}
\hline \multirow[t]{2}{*}{ Perlakuan } & \multicolumn{4}{|c|}{ Umur Tanaman } \\
\hline & $1 \mathrm{MST}$ & $2 \mathrm{MST}$ & $3 \mathrm{MST}$ & $4 \mathrm{MST}$ \\
\hline B1 & $4,57 \mathbf{a}$ & $7,24 \mathbf{a}$ & $9,32 \mathbf{a}$ & $11,67 \mathbf{a}$ \\
\hline B2 & $5,17 \mathbf{a}$ & $9,21 \mathbf{b}$ & $10,33 \mathbf{a}$ & $16,67 \mathbf{b}$ \\
\hline B3 & $6,48 \mathbf{a}$ & $10,84 \mathbf{b}$ & $13,76 \mathbf{b}$ & $22,01 \mathbf{c}$ \\
\hline B4 & $9,31 \mathbf{b}$ & $16,59 \mathrm{c}$ & $19,58 \mathbf{c}$ & 25,48 cd \\
\hline B5 & $9,87 \mathbf{b}$ & $17,38 \mathbf{c}$ & $23,10 \mathbf{d}$ & $25,94 \mathbf{c}$ \\
\hline BNJ 5\% & 2,21 & 1,71 & 2,96 & 3,77 \\
\hline
\end{tabular}


Keterangan : Angka- yang ditandai oleh huruf yang sama tidak berbeda nyata pada taraf uji BNJ 5\% Hasil uji BNJ $5 \%$ (Tabel 1) menunjukkan bahwa pada umur 1, 2, 3 dan 4 MST perlakuan B5 menghasilkan tinggi tanaman yang lebih tinggi dimana pada umur 1 MST perlakuan B5 berbeda nyata dengan perlakuan B1, B2 dan B3 akan tetapi berbeda tidak nyata dengan perlakuan B4. Sementara pada umur 2 MST perlakuan B5 berbeda nyata dengan perlakuan B1 akan tetapi berbeda tidak nyata dengan perlakuan B2, B3 dan B4. Pada umur 3 MST perlakuan B5 berbeda nyata dengan perlakuan B1 dan B2 akan tetapi berbeda tidak nyata dengan perlakuan B3 dan B4. Sedangkan pada umur 4 MST perlakuan B5 berbeda nyata dengan perlakuan B1 akan tetapi berbeda tidak nyata dengan perlakuan B2, B3 dan B4.

Hasil penelitian menunjukkan bahwa tanaman tertinggi dihasilkan oleh perlakuan B5 (MOL nasi). Hal ini di duga karena unsur hara yang digunakan oleh tanaman pakcoy dalam pertumbuhan vegetative terkandung unsur nitrogen yang tinggi dalam MOL nasi. Anwar dkk., (2008) menjelaskan bahwa Nitrogen merupakan unsur hara utama bagi pertumbuhan tanaman, yang pada umumnya sangat diperlukan untuk pembentukan atau pertumbuhan bagianbagian vegetatif tanaman, seperti daun, batang dan akar. MOL nasi juga mengandung bakteri Sacharomycees dan Lactobacillus yaitu mikroorganisme pengurai dan penyubur tanaman.

Hasil Uji BNJ 5\% menunjukkan bahwa pada umur 1, 2, 3 dan 4 MST perlakuan B5 memperlihatkan jumlah daun terbanyak berbeda nyata dengan perlakuan B1, B2, B3 dan B4. Berdasarkan data (Tabel 2) menunjukkan bahwa jumlah daun terbanyak dihasilkan pada perlakuan B5 (MOL nasi). Hal ini diduga kandungan nitrogen dalam mol nasi dapat mencukupi kebutuhan untuk pertumbuhan tanaman pakcoy. Lestari, et.al, (2017), menyatakan bahwa bagian tanaman sawi yang dikonsumsi adalah bagian daun sehingga pupuk yang diberikan sebaiknya mengandung nitrogen (N) tinggi. Sifat pupuk N mudah menguap dan ketika musim penghujan dapat terjadi pencucian. Ketika tanaman kekurangan unsur hara nitrogen menunjukkan gejala daun menguning, sehingga pengaplikasian pupuk $\mathrm{N}$ kepada tanaman harus tetap terpenuhi. Kandungan $\mathrm{N}$ paling tinggi terdapat dalam MOL nasi karena bahan baku utama MOL nasi adalah nasi yang merupakan hasil dari pematangan biji beras. Biji sebagai sumber karbon, unsur hara utamanya adalah $\mathrm{N}$ dan $\mathrm{P}$. Kandungan N dalam biji beras 7.13 g, lebih tinggi bila dibandingkan dengan unsur hara lainnya (Lamont \& Groom 2013).

Hasil analisis ragam menunjukkan bahwa pemberian berbagai jenis MOL berpengaruh nyata terhadap jumlah daun tanaman pakcoy pada umur 1 hingga 4 MST. Rata-rata jumlah daun tanaman pakchoy umu 1-4 MST disajikan pada Tabel 2.

\section{Jumlah Daun}

Tabel 2. Rata-Rata Jumlah Daun Tanaman Pakcoy Pada Umur 1 MST, 2 MST, 3 MST dan 4 MST

\begin{tabular}{ccccc}
\hline \multirow{2}{*}{ Perlakuan } & \multicolumn{4}{c}{ Umur Tanaman } \\
& 1 MST & 2 MST & 3 MST & 4 MST \\
\hline B1 & $3,20 \mathbf{a}$ & $4,27 \mathbf{a}$ & $5,16 \mathbf{a}$ & $6,08 \mathbf{~ a}$ \\
B2 & $4,68 \mathbf{b}$ & $5,54 \mathbf{~ b}$ & $6,85 \mathbf{a b}$ & $12,88 \mathbf{b}$ \\
B3 & $4,72 \mathbf{b}$ & $5,78 \mathbf{~ b}$ & $8,00 \mathbf{b}$ & $14,25 \mathbf{b}$ \\
B4 & $4,80 \mathbf{b}$ & $6,33 \mathbf{~ b}$ & $11,52 \mathbf{c}$ & $17,72 \mathbf{c}$ \\
B5 & $5,38 \mathbf{c}$ & $8,66 \mathbf{c}$ & $12,78 \mathbf{c}$ & $19,98 \mathbf{c}$ \\
\hline BNJ 5\% & 0,59 & 0,95 & 1,90 & 3,43 \\
\hline
\end{tabular}

Keterangan: Angka yang ditandai oleh huruf yang sama tidak berbeda nyata pada taraf uji BNJ $5 \%$

\section{Panjang Daun (cm)}

Hasil analisis ragam menunjukkan pemberian berbagai jenis MOLberpengaruh sangat nyata terhadap panjang daun tanaman pakcoy umur 1 - 4 MST. Rata-rata Panjang daun pakchoy umur 1-4 MST disajikan pada Tabel 3. 
Tabel 3. Rata-Rata Panjang Daun Tanaman Pakcoy Pada Umur 1 MST, 2 MST, 3 MST dan 4 MST

\begin{tabular}{ccccc}
\hline Perlakuan & \multicolumn{4}{c}{ Umur Tanaman } \\
\cline { 2 - 5 } & 1 MST & 2 MST & 3 MST & 4 MST \\
\hline B1 & $1,86 \mathbf{a}$ & $3,60 \mathbf{a}$ & $4,35 \mathbf{a}$ & $5,94 \mathbf{a}$ \\
B2 & $2,37 \mathbf{a}$ & $3,82 \mathbf{a}$ & $4,83 \mathbf{a}$ & $5,21 \mathbf{a}$ \\
B3 & $3,14 \mathbf{b}$ & $4,92 \mathbf{b}$ & $4,99 \mathbf{a}$ & $8,02 \mathbf{b}$ \\
B4 & $4,98 \mathbf{c}$ & $5,64 \mathbf{b}$ & $6,71 \mathbf{b}$ & $8,44 \mathbf{b c}$ \\
B5 & $5,46 \mathbf{c}$ & $6,53 \mathbf{c}$ & $7,03 \mathbf{~}$ & $9,59 \mathbf{c}$ \\
\hline BNJ 5\% & 1,07 & 1,08 & 1,54 & 1,28 \\
\hline
\end{tabular}

Keterangan: Angka-angka yang ditandai oleh huruf yang sama menunjukkan berbeda tidak nyata pada taraf Uji BNJ 5\%

.Hasil Uji BNJ 5\% menunjukkan bahwa pada umur 1, 2, 3 dan 4 MST perlakuan B5 memperlihatkan panjang daun terpanjang dimana pada umur 1 MST dan 2 MST perlakuan B5 berbeda nyata dengan perlakuan B1 dan B2 akan tetapi berbeda tidak nyata dengan perlakuan B3 dan B4. Sementara pada umur 3 MST perlakuan B5 berbeda nyata dengan perlakuan B1, B2 dan B3 akan tetapi berbeda tidak nyata dengan perlakuan B4. Sedangkan pada umur 4 MST perlakuan B5 berbeda nyata dengan perlakuan B1 dan B2 akan tetapi berbeda tidak nyata dengan perlakuan B3 dan B4.

Berdasarkan data (Tabel 3), menunjukkan bahwa MOL nasi menghasilkan daun terpanjang pada tanaman pakcoy. Hal ini diduga karena kandungan mikroba yang terdapat dalam MOL nasi dapat mengurai unsur hara tersedia menjadi nitrogen yang berguna dalam pembentukan daun. Bakteri pengurai yang terdapat dalam Tabel 3. Rata-Rata Panjang Daun Tanaman Pakcoy Pada Umur 1 MST, 2 MST, 3 MST dan 4 MST Perlakuan
MOL dengan media nasi basi, mengandung unsur mikro dan makro serta mengandung bakteri yang berpotensi sebagai perombak bahan organik, perangsang tumbuhan, dan sebagai agens pengendali hama dan penyakit tanaman, sehingga MOL dapat digunakan baik sebagai pendekomposer pupuk hayati dan sebagai pestisida organik terutama sebagai fungisida (Purwasasmita, 2009).

\section{Lebar Daun (cm)}

Hasil analisis ragam menunjukkan bahwa pemberian berbagai jenis mikroorganisme lokal (MOL) berpengaruh nyata terhadap lebar daun tanaman tanaman pakcoy pada umur 1 hingga 4 MST. Rata-rata lebar daun tanaman pakchoy umur 1-4 MST disajikan pada Tabel 4.

\begin{tabular}{ccccc} 
& 1 MST & 2 MST & 3 MST & 4 MST \\
\hline B1 & $1,19 \mathbf{a}$ & $1,50 \mathbf{a}$ & $1,78 \mathbf{a}$ & $2,61 \mathbf{a}$ \\
B2 & $1,72 \mathbf{~ b}$ & $1,97 \mathbf{b}$ & $2,90 \mathbf{b}$ & $3,70 \mathbf{b}$ \\
B3 & $1,85 \mathbf{~ b}$ & $2,37 \mathbf{b}$ & $2,93 \mathbf{b}$ & $3,75 \mathbf{b}$ \\
B4 & $2,89 \mathbf{c}$ & $3,30 \mathbf{c}$ & $3,65 \mathbf{c}$ & $4,50 \mathbf{b}$ \\
B5 & $3,54 \mathbf{d}$ & $3,83 \mathbf{c}$ & $4,01 \mathbf{c}$ & $5,71 \mathbf{c}$ \\
\hline BNJ 5\% & 0,54 & 0,67 & 0,65 & 0,95 \\
\hline
\end{tabular}

Keterangan: Angka-angka yang ditandai oleh huruf yang sama menunjukkan berbeda tidak nyata pada taraf Uji BNJ $5 \%$.

Hasil Uji BNJ 5\% menunjukkan bahwa pada umur 1, 2, 3 dan 4 MST perlakuan B5 memperlihatkan panjang daun terpanjang dimana pada umur 1 MST dan 2 MST perlakuan B5 berbeda nyata dengan perlakuan B1 dan B2 akan tetapi berbeda tidak nyata dengan perlakuan B3 dan B4. Sementara pada umur 3 MST perlakuan B5 berbeda nyata dengan perlakuan B1, B2 dan B3 akan tetapi berbeda tidak nyata dengan perlakuan B4. Sedangkan pada umur 4 MST perlakuan B5 berbeda nyata dengan perlakuan B1 dan B2 akan tetapi berbeda tidak nyata dengan perlakuan B3 dan B4.

Berdasarkan data (Tabel 3), menunjukkan bahwa MOL nasi menghasilkan daun terpanjang pada tanaman pakcoy. Hal ini diduga karena kandungan mikroba yang terdapat dalam MOL 
nasi dapat mengurai unsur hara tersedia menjadi nitrogen yang berguna dalam pembentukan daun. Bakteri pengurai yang terdapat dalam MOL dengan media nasi basi, mengandung unsur mikro dan makro serta mengandung bakteri yang berpotensi sebagai perombak bahan organik, perangsang tumbuhan, dan sebagai agens pengendali hama dan penyakit tanaman, sehingga MOL dapat digunakan baik sebagai pendekomposer pupuk hayati dan sebagai pestisida organik terutama sebagai fungisida (Purwasasmita, 2009).

\section{Lebar Daun (cm)}

Hasil analisis ragam menunjukkan bahwa pemberian berbagai jenis mikroorganisme lokal (MOL) berpengaruh nyata terhadap lebar daun tanaman tanaman pakcoy pada umur 1 hingga 4 MST. Rata-rata lebar daun tanaman pakchoy umur 1-4 MST disajikan pada Tabel 4.

Tabel 4. Rata-Rata Lebar Daun Tanaman Pakcoy Pada Umur 1 MST, 2 MST, 3 MST dan 4 MST Perlakuan Umur Tanaman

\begin{tabular}{ccccc} 
& 1 MST & 2 MST & 3 MST & 4 MST \\
\hline B1 & $1,19 \mathbf{a}$ & $1,50 \mathbf{a}$ & $1,78 \mathbf{a}$ & $2,61 \mathbf{a}$ \\
B2 & $1,72 \mathbf{b}$ & $1,97 \mathbf{b}$ & $2,90 \mathbf{b}$ & $3,70 \mathbf{b}$ \\
B3 & $1,85 \mathbf{b}$ & $2,37 \mathbf{b}$ & $2,93 \mathbf{b}$ & $3,75 \mathbf{b}$ \\
B4 & $2,89 \mathbf{c}$ & $3,30 \mathbf{c}$ & $3,65 \mathbf{c}$ & $4,50 \mathbf{b}$ \\
B5 & $3,54 \mathbf{d}$ & $3,83 \mathbf{c}$ & $4,01 \mathbf{c}$ & $5,71 \mathbf{c}$ \\
\hline
\end{tabular}

Keterangan: Angka-angka yang ditandai oleh huruf yang sama menunjukkan berbeda tidak nyata pada taraf Uji BNJ 5\%.

Hasil Uji BNJ 5\% menunjukkan bahwa pada umur 1, 2, 3 dan 4 MST perlakuan B5 memperlihatkan lebar daun terlebar dimana perlakuan B5 berbeda nyata dengan perlakuan B1 akan tetapi berbeda tidak nyata dengan perlakuan B2, B3 dan B4. Berdasarkan data (Tabel 4) menunjukkan bahwa MOL nasi menghasilkan daun terlebar pada tanaman pakcoy. Hal ini diduga karena kandungan hara yang diperlukan dalam pelebaran daun seperti nitrogen dapat dihasilkan dalam MOL nasi. Oktiningtyas (2015), menyatakan bahwa pertumbuhan lebar daun pada tanaman Tabel 5. Rata-Rata Berat Segar Tanaman Pakcoy

\begin{tabular}{cc}
\hline Perlakuan & Rata-Rata Berat Segar Tanaman Pakcoy \\
\hline B1 & $19,49 \mathbf{a}$ \\
B2 & $24,53 \mathbf{a b}$ \\
B3 & $32,27 \mathbf{~ b}$ \\
B4 & $56,54 \mathbf{c}$ \\
B5 & $68,48 \mathbf{c}$ \\
\hline BNJ 5\% & 10,88 \\
\hline
\end{tabular}

Keterangan: Angka-angka yang ditandai oleh huruf yang sama menunjukkan berbeda tidak nyata pada taraf Uji BNJ 5\%

Hasil Uji BNJ 5\% menunjukkan bahwa perlakuan B5 memperlihatkan berat segar terberat dimana perlakuan B5 berbeda nyata dengan perlakuan B1 akan tetapi berbeda tidak nyata dengan perlakuan B2, B3 dan B4. Berdasrkan data (Tabel 5) menunjukkan bahwa pemberian MOL nasi menghasilkan tanaman pakcoy paling berat dibandingkan MOL lainnya. dipengaruhi nutrisi yang terkandung dalam mol, seperti halnya pada pertumbuhan jumlah daun, nutrisi yang berperan penting terhadap pertumbuhan lebar daun adalah nitrogen, dan nutrisi lain, seperti posfor, kalsium, karbohidrat dan lainnya.

\section{Berat Segar Tanaman}

Hasil analisis ragam menunjukkan bahwa pemberian berbagai jenis mikroorganisme lokal (MOL) pada tanaman pakcoy berpengaruh sangat nyata terhadap berat basah tanaman pakcoy. Rata-rata berat segar tanaman pakchoy disajikan pada Tabel 5 .
Hal ini di duga karena pengaruh penyerapan unsur hara dan penimbunan hasil fotosintesis dalam tumbuhan. Maka semakin optimal unsur hara dalam pupuk akan semakin menambah berat basah tanaman pakcoy. Menurut Sukmawati (2012), Pemberian unsur $N$ dan $P$ yang cukup dapat membantu mengubah karbohidrat yang dihasilkan dalam proses 
fotosintesis menjadi protein sehingga akan membantu menambah lebar, panjang dan jumlah daun. Berat basah juga dipengaruhi oleh jumlah daun. Hasil ini sesuai dengan pernyataan Polii (2009) dalam penelitiannya yang mengemukakan bahwa dengan meningkatnya jumlah daun tanaman maka akan secara otomatis meningkatkan berat segar tanaman, Selain itu daun pada tanaman sayuran merupakan organ yang banyak mengandung air, sehingga dengan jumlah daun yang semakin banyak maka kadar air tanaman akan tinggi dan menyebabkan berat segar tanaman semakin tinggi pula.

\section{KESIMPULAN}

Dari hasil penelitian dapat disimpulkan bahwa pemberian mol nasi merupakan perlakuan yang lebih baik terhadap tinggi tanaman, jumlah daun, panjang daun dan lebar daun hingga minggu keempat yaitu masingmasing 25,$94 ; 19,98 ; 9,59 ; 5,71 ;$ dan berat segar tanaman pakcoy yaitu 68,48 .

\section{DAFTAR PUSTAKA}

Adiwilaga. 2010. Faktor-faktor yang Mempengaruhi Sisi Permintaan dan Sisi Penawaran Sayuran Sawi. Bandung: Penerbit Alumni Bandung.

Anwar, K., Rangga, F., Kifli, H., Ridha, I M., Lestari, P. P., \& Wulandari, H. 2008. Prosiding Seminar Nasional Teknoin '08 Bidang Teknik Kimia: Kombinasi limbah pertanian dan peternakan sebagai alternatif pembuatan pupuk organik cair melalui proses fermentasi anaerob. Yogyakarta: Jurusan Teknik Kimia fakultas Teknologi Industri Universitas Islam Indonesia Diakses 16 Januari 2019.

Badan Pusat Statistik dan Direktorat Jendral Hortikultura. 2018. Produksi Sayuran di Indonesia, Tahun 2014-2018. Diakses tanggal 20 November 2019.

Indarjaya, A.R dan suhartini. 2018. Uji Kualitas Dan Efektivitas Poc Dari Mol Limbah Sayuran Terhadap Pertumbuhan Dan Produktivitas Sawi. Jurnal Prodi Biologi Vol 7 No 8.

Lamont, B.B., dan P.K. Groom. 2013. Seed as a source carbon, nitrogen and phosphorus for seedling establishment in temperate regions. Plant Sci. 4:30-40. Jurnal Tanah dan Iklim Vol. 40 No. 1 - 2016: 71-78 Diakses 16 Januari 2018.

Lestari, SU, N.Susi dan E.Mutryarny. 2017. Pengujian Mikroorganisme Lokal (MOL) Limbah Sayuran Terhadap Pertumbuhan Dan Produksi Tanaman Sawi (Brassica juncea
L).Jurnal Ilmiah Pertanian Vol. 14 No.1, Agustus 2017. Diakses 16 Januari 2018

Oktiningtiyas, L. 2015. Efektifitas Mikroorganisme Lokal (Mol) Kulit Pisang Dan Bonggol Pisang Terhadap Pertumbuhan Tanaman Selada (Lactuca Sativa L) Pada Media Hidroponik, Naskah Publikasi,Fakultas Keguruan Dan Ilmu Pendidikan Universitas Muhammadiyah, Surakarta.

Perwitasari, Belia, Mustika T, Catur W. 2012. Pengaruh Media Tanam dan NutrisiTerhadap Pertumbuhan Tanaman Pakcoy (Brassica juncea) dengan SistemHidroponik. Jurnal Argovigor 5(1): 15 Diakses 27 Mei 2017.

Polii, G.M.M. 2009. Respon Produksi Tanaman Kangkung Darat (Ipomea reptans Poir.) Terhadap Variasi Waktu Pemberian Pupuk Kotoran Ayam. Journal Soil Environment Vol.VII No.1. hlm 5. diakses 16 Januari 2018

Purwasasmita M, 2009. Mikroorganisme Lokal sebagai Pemicu Siklus Kehidupan Dalam Bioreaktor Tanaman. Seminar Nasional teknik Kimia, Bandung 19-20 Oktober 2009.

Sukmawati,S. 2012. Budidaya pakchoi (Brassica chinensil L.) secara organik dengan pengaruh beberapa jenis pupuk organik [Karya Ilmiah]. Lampung: Politeknik Negeri Lampung. diakses 16 Januari 2019

Suparyono, 2011. Pengaruh Pemberian Mikroorganisme Lokal (Mol) Bonggol Pisang Nangka Terhadap Produksi Rosella (Hibiscus sabdariffa l)

Purwasasmita, M. 2009. Mikroorganisme Lokal Sebagai Pemicu Siklus Kehidupan dalam Bioreaktor. Tanaman. Seminar Nasional Teknik Kimia Indonesia. 19 -20 Oktober 2009. 